\title{
Introvert and extrovert personality: Is it correlated with academic achievement of Physical Education, Health and Recreation students at university level?
}

\author{
Hasanuddin Jumareng ${ }^{1, *(1)}$, Wolter Mongsidi ${ }^{1}$, Edi Setiawan ${ }^{2}(\mathbb{D}$ \\ Ihsan Abdul Patah ${ }^{2}$, Adi Rahadian ${ }^{2}$, Ruslan Abdul Gani ${ }^{3}$ \\ Universitas Halu Oleo, Indonesia ${ }^{1}$ \\ Universitas Suryakancana, Indonesia ${ }^{2}$ \\ Universitas Singaperbangsa Karawang, Indonesia ${ }^{3}$
}

Received: 27 January 2021; Accepted 08 April 2021; 20 July 2021

Ed 2021; 6(2): 140-146

\begin{abstract}
Psychological elements, namely introverted and extroverted personalities, are currently one of the keys to determining success in academics at the University level, but it is not clear which type is more correlated with academic achievement. The purpose of this study is to investigate the correlation between introverted and extroverted personalities with student academic achievement. The subjects in this study come from the PJKR Department of the University of Suryakancana $(\mathrm{N}=20)$ and Halu Oleo $(\mathrm{N}=20)$. Data analysis uses SPSS version 25 to find descriptive statistics, normality, data linearity and person product moment correlation. The level of significance used is 0.05 . The results of the study finds that introverted personality is significantly correlated with academic achievement in the high category $\left(\mathrm{r}=0.749^{* *}\right)$, and extroverted personality is not significantly correlated with academic achievement $(\mathrm{r}=-0.120)$. Thus, it can be concluded that the personality of students with introverted type is far superior to extroverts in academic achievement at the University level. The contribution in this study contributes to knowledge in the field of physical education psychology, so that later lecturers can pay more attention and optimize academic achievement in students with both types, especially the extroverted type.
\end{abstract}

Keywords: Introverts; extrovert; academic achievement; physical education

d.

https://doi.org/10.25299/sportarea.2021.vol6(2).6172

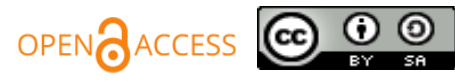

Copyright @ 2021 Hasanuddin Jumareng, Wolter Mongsidi, Edi Setiawan, Ihsan Abdul Patah, Adi Rahadian, Ruslan Abdul Gani

Corresponding author: Hasanuddin Jumareng, Department of Physical Education, Health and Recreation, Universitas Halu Oleo, Kendari, Indonesia

Email: hasanuddinjumareng@uho.ac.id

How to Cite: Jumareng, H., Mongsidi, W., Setiawan, E ., Patah, I. A., Rahadian, A., \& Gani, R. A. (2021). Introvert and extrovert personality: Is it correlated with academic achievement of Physical Education, Health and Recreation students at university level?. Journal Sport Area, 6(2), 140-146. https://doi.org/10.25299/sportarea.2021.vol6(2).6172

\section{INTRODUCTION}

Academic achievement is a goal that must be achieved as best as possible by all students when undergoing the physical education learning process during lectures. In addition, academic achievement is also one of the parameters to assess the extent to which students can achieve success, it can even be used to see the effectiveness and quality of teaching applied by a lecturer. Academic achievement is considered as one of the important criteria to see the quality of education applied at a university (Hakimi, Hejazi, \& Lavasani, 2011). Therefore, it is important to see what factors are significantly correlated with student academic achievement. 
Personality is one of the concepts in psychological science that is very important and is the key to the success or failure of students in undergoing academic activities both at the elementary school and at university level (Hakimi et al., 2011; Prakash, Singh, \& Yadav, 2016). Personality basically has a meaning as a behavior, habit, nature, character, character which is the hallmark of an individual (Aşçi, Lindwall, Altintaş, \& Edepli Gürsel, 2015; Rhodes \& Boudreau, 2017). A person's personality is determined by two factors, namely heredity and environment, where both of these factors will play a role in producing a good or bad personality (Baro \& Buragohain, 2014). No two humans on this earth have the same personality, every human being must have a personality with their own characteristics. Personality is divided into several types, namely introvert which is a personality type of someone who tends to show behavior, such as quiet, shy (Afshan, Askari, Sam, \& Manickam, 2015), be more careful, can control their emotions well, do not have many friends, difficult to establish relationships with others, likes concentration and solitude, prefers to do tasks independently, and less socialize. In physical education learning situations, such as during class discussions, students who have introverted personalities tend to be reluctant to share their ideas, ideas or opinions with others (Prakash et al., 2016). According to Sumantri and Pratiwi (2015) someone who has an introverted personality type tends to be better than an extroverted type in terms of thinking and acting, receiving and processing information better, more active in learning, and faster at work. While extrovert is the personality of someone who tends to show behavior, such as energetic (Roslan et al., 2019), bold, active, assertive (Farsani, Azadi, Farsani, \& Aroufzad, 2013), friendly, sociable, talkative, has many friends, easy to get along with (Salehi, 2010), always need a friend to talk to, happy to discuss, but more careless in making decisions (Stylianos et al., 2014). In physical education learning situations, students with extroverted personalities tend to want to help their friends who have difficulties in learning. The results of previous studies reported that the male and female groups differed significantly in personality and the findings found that women scored higher than men in academic achievement (Cavallera et al., 2014). In addition, the research results Allen, Greenlees, and Jones (2013) shows that student personality is closely related to increased achievement in physical education learning. In fact, it is claimed to have a correlation with sports activities, so that it becomes more optimal (Cavallera et al., 2014). For example, athletes who have certain personalities, such as being calmer when dealing with problems, can control stress, do not have high emotions (Merritt \& Tharp, 2013), these characteristics are more likely to achieve high achievements in professional sports (Laborde, Guillén, \& Mosley, 2016).

Although previous studies have shown that both introverted and extroverted personalities are associated with increased achievement in physical education learning, there are still gaps in previous studies which show that there is no significant difference between introverted and extroverted personalities (Prakash et al., 2016). In addition, other studies report that there is no significant relationship between learning outcomes with extroverted and introverted personality of students (Ariga, Amelia, \& Sari, 2018). With the existence of several gaps in previous studies, this becomes the urgency of the research. In addition, this study offers a very important benefit, namely adding to the literature on introverted and extroverted personalities in the field of physical education in Indonesia, so it is appropriate for researchers to follow up on this research.

Several previous studies that have been carried out regarding introverted and extroverted personalities, include: the relationships between personality traits and students' academic achievement (Hakimi et al., 2011), personality (introvert, and extrovert) and professional commitment effect among B.Ed teacher educator students (Prakash et al., 2016), shyness, self-construal, extraversion-introversion, neuroticism, and psychoticism: a cross-cultural comparison among college students (Afshan et al., 2015) the role of personality in sport and physical activity (Allen \& Laborde, 2014), trait personality in sport and exercise psychology: A mapping review and research agenda (Laborde, Allen, Katschak, Mattonet, \& Lachner, 2020), however, there is no previous study that reports on the correlation between introverted and extroverted personalities with academic achievement of Physical Education, Health and Recreation students at the university level, so that is what is new in this study. If this research is not carried out, it will affect and hinder the academic achievement of Physical Education, Health and Recreation students. In addition, this study is different from previous studies because it is carried out in a pandemic condition. Therefore, the purpose of this study is to investigate the correlation between introverted and extroverted personalities with academic achievement. The hypotheses in this study are: (H1) introverted personality is correlated with student academic achievement, 
(H2) extroverted type personality is not correlated with student academic achievement, (H3) introverted type personality is more correlated than extroverted type with student academic achievement.

\section{METHODS}

The approach used is quantitative with descriptive correlation method. Correlation research is a study to see whether or not there is a relationship or correlation between one variable and another.

\section{Population and Sample}

The population in this study is male students aged 18 to 20 years from level II in the Department of Physical Education, Health and Recreation from Suryakancana University $(\mathrm{N}=20)$ and Halu Oleo $(\mathrm{N}=20)$, so the total population is 40 students. The sampling technique used in this research is purposive sampling, which is a selection of subjects based on certain criteria or considerations. The criteria used are: (1) having introverted and extroverted personalities, (2) having basic knowledge of sports psychology. Before starting the study, all subjects are asked to write a question letter about their willingness to participate in all activities in this study.

\section{Research Instrument}

The instrument used to measure the introverted and extroverted personality of students can use the Eysenck Personality Questionnaire-Revised (EPQ-R). This instrument is specifically for measuring introverted and extroverted personalities (Afshan et al., 2015). This instrument has indicators, including: sociability, impulsiveness, activity, liveness, and exitability. To fill out this questionnaire, you can use a Likert scale consisting of strongly agree ( 5 points), agree (4 points), disagree ( 3 points), disagree ( 2 points), and strongly disagree (1 point). The instrument has been tested beforehand and it has a level of validity $(0.88)$ and reliability (0.79). Meanwhile, the instrument for measuring academic achievement of students can use the final score in all physical education courses in one semester.

\section{Research Procedure}

This research is conducted from 7 to 8 January 2020 and has obtained permission from the Department of Physical Education, Health and Recreation at Suryakancana University and Halu Oleo University. This research is conducted through an online system (google meet), where the Eysenck Personality QuestionnaireRevised file is sent to all subjects and they are given 30 minutes to fill out the questionnaire at their respective homes. After the subjects finish filling out the Eysenck Personality Questionnaire-Revised, the files from the questionnaire are sent back to the researchers via email and then analyzed by experts in the field of sports psychology.

\section{Data Analysis Technique}

At the data analysis stage in this study, the IBM SPSS software SPSS version 25 is used to perform statistical descriptive tests (mean and standard deviation) of normality (Shapiro-Wilk), data linearity (Setiawan, Budiarto, \& Afriyuandi, 2020), and person product moment correlation (Setiawan et al., 2020). The level of significance used is 0.05 .

\section{RESULTS AND DISCUSSION}

The results of this study find very important information, including: testing the normality of the data stated to be normally distributed (0.129) and linearity indicated that there is a linear correlation between introverted and extroverted personalities with academic achievement (0.133) and the results of statistical descriptive tests are presented in Table 1. While The results of testing the person product moment correlation of the two personality types between introverts and extroverts are presented in Table 2. 
Table 1. Statistic Descriptive

\begin{tabular}{ccccc}
\hline Variables & N & Mean & SD \\
\hline Introvert & 40 & 30.10 & 5.40 \\
Extrovert & 40 & 27.45 & 11.01 \\
Academic Achievement & 40 & 27.81 & 8.90 \\
\hline
\end{tabular}

Based on Table 1 above, it can be seen that the introvert variable has a mean value of 30.10 and a standard deviation of 5.40 and for the extrovert variable it has a mean value of 27.45 and a standard deviation of 11.01. Meanwhile, for the academic achievement variable, the mean value is 27.81 and the standard deviation is 58.90 .

Table 2. The Correlation between Introvert and Extrovert with Academic Achievement

\begin{tabular}{cccc}
\hline Variables & $\mathbf{N}$ & $\mathbf{r}$ & $\boldsymbol{P}$-value \\
\hline Introvert with Academic Achievement & 40 & $0.749^{* * *}$ & 0.002 \\
Extrovert with Academic Achievement & 40 & -0.120 & 0.122 \\
\hline
\end{tabular}

Based on the correlation test presented in Table 2 and data obtained that the correlation coefficient of the introvert variable with academic achievement $(0.749 * *)$, this data means that there is a significant correlation with the high category. While the correlation coefficient of the extroverted variable with academic achievement (-0.120), the data means that there is no significant correlation with the very low category. When it is observed on the correlation coefficient, it shows that the introvert variable has a greater value than the extrovert on academic achievement.

The purpose of this study is to investigate the correlation between introverted and extroverted personality types with student academic achievement at the university level. The results of this study finds that the introverted personality has a significant correlation with the high category on academic achievement, this is because the introverted personality type tends to be more serious and focused on doing the assignments given by the lecturer. In addition, students with introverted personalities have a much higher level of concentration and motivation than extroverts when carrying out physical education lectures (Hartono, Berliana, \& Mulyana, 2019). The same finding was reported by a previous study which explained that higher academic achievement in students with introverted personality types was due to their having effective study habits and higher concentration abilities in the classroom (Hakimi et al., 2011). Another study found that the hallmark of someone who has an introverted personality type is concentration with a percentage gain of $65 \%$ compared to other traits in introverts (Cholil, 2010). Thus, it can be concluded that the results of this study support previous research.

Another finding in this study shows that the extroverted personality type has no correlation with academic achievement, this is because students with extroverted types tend to be more careless in doing assignments and want to finish quickly on exams, regardless of whether the answer is correct or not. This finding is in line with previous studies which reported that someone who has an extroverted personality is more likely to make mistakes in doing things and find it difficult to be serious in learning (Hakimi et al., 2011; Afshan et al., 2015). In addition, extrovert personalities are claimed to always joke and never take the learning process seriously in class or during practice in the field (Salehi, 2010), thus more prone to lower academic achievement. Lower academic achievement in students with extroverted personalities can be caused by several factors, for example students are not serious in doing assignments, are not focused and concentrate less on taking exams, high levels of doubt in doing assignments, and lack of motivation to study at home (Jenaabadi, 2017). Thus, in this study finds a fact that in physical education lectures at the university level students with introverted personality types will get much better academic achievements than extroverts.

The impact of this research will provide scientific insight for Physical Education, Health and Recreation lecturers regarding introverted and extroverted personalities, so that lecturers can pay more attention to students with extroverted personality types who tend to have lower academic achievements. The same result was reported by Zeichner (2019) that introverts and extroverts have a significant difference in student achievement. 


\section{CONCLUSION}

Based on the explanation in the results and discussion section, this study confirms that the personality of Physical Education, Health and Recreation students with the introverted type shows a much greater correlation to academic achievement than the extrovert type. There are several limitations in this study, among others: the subjects used are relatively few and only come from one department, namely Physical Education, Health and Recreation from Suryakancana and Halu Oleo Universities, and filling out the questionnaire by the subject should be done directly on campus and supervised by researchers, so that it can be controlled well and get a more accurate answer. However, this research has implications, namely knowledge in the field of psychology education, especially for teachers, lecturers, students, and practitioners of psychology about the important aspects of personality for students to achieve high academic achievement. Future research needs to be done by adding more research subjects from several departments at the Faculty of Teacher Training and Education (FKIP) in Indonesia. In addition, you can also add other independent variables, such as investigating the personality of the abrivert type.

\section{REFERENCES}

Afshan, A., Askari, I., Sam, L., \& Manickam, S. (2015). Shyness, Self-Construal, Extraversion-Introversion, Neuroticism, and Psychoticism: A Cross-Cultural Comparison Among College Students. SAGE Open, (April), 1-8. https://doi.org/10.1177/2158244015587559

Allen, M. S., Greenlees, I., \& Jones, M. (2013). Personality in sport: A comprehensive review. International Review of Sport and Exercise Psychology, 6(1), 184-208. https://doi.org/10.1080/1750984X.2013.769614

Allen, M. S., \& Laborde, S. (2014). The Role of Personality in Sport and Physical Activity. Current Directions in Psychological Science, 23(6), 460-465. https://doi.org/10.1177/0963721414550705

Ariga, R. A., Amelia, R., \& Sari, S. (2018). Relationship of extrovert and introvert personality types against student achievement faculty of nursing USU. Journal of Physics: Conference Series, 1116(5). 1-8. https://doi.org/10.1088/1742-6596/1116/5/052007

Aşçi, F. H., Lindwall, M., Altintaş, A., \& Edepli Gürsel, N. (2015). Gender differences in the relation of personality traits and self-presentation with physical activity. Science and Sports, 30(1), e23-e30. https://doi.org/10.1016/j.scispo.2014.07.016

Baro, M., \& Buragohain, M. (2014). A Comparative Study of Personality Traits between Physical Education and General Education Teachers of Assam. Research Journal of Physical Education Sciences, 2(8), 1719.

Cavallera, Guido, M., Passerini, A., \& Pepe, A. (2014). Personality Traits and The Role of Gender in Swimmers at the Leisure Level. Social Behavior and Personality, 4(4), 693-704. https://doi.org/10.2224/sbp.2013.41.4.693

Cholil, D. H. (2010). Profil Kepribadian Atlet Yunior Tae Kwon Do Kota Bandung. Interagir: Pensando a Extensão, 2(2), 38-50. https://doi.org/10.17509/jko-upi.v2i2.16196

Farsani, M. E., Azadi, A., Farsani, F. A., \& Aroufzad, S. (2013). Relationship between leadership styles and personality traits among woman physical education teachers, 2(1), 17-21. 
Hakimi, S., Hejazi, E., \& Lavasani, M. G. (2011). The relationships between personality traits and students' academic achievement. Procedia - Social and Behavioral Sciences, 29, 836-845. https://doi.org/10.1016/j.sbspro.2011.11.312

Hartono, T., Berliana, \& Mulyana. (2019). Peningkatan Responsibility Melalui Penerapan Model Pembelajaran Ditinjau dari Kepribadian Extrovert dan Introvert Siswa Responsibility Improvement Through the Application of Learning Models Viewed from Extroverted and Introverted Personality of Students, (4), 127-135.

Jenaabadi, H. (2017). The Relationship of Personality Type, Social Trust and Social Desirability among the Homeless Adolescents Living in Zahedan Welfare Organization Hostels, 11(1), 5-27.

Laborde, S., Allen, M. S., Katschak, K., Mattonet, K., \& Lachner, N. (2020). Trait personality in sport and exercise psychology: A mapping review and research agenda. International Journal of Sport and Exercise Psychology, 18(6), 701-716. https://doi.org/10.1080/1612197X.2019.1570536

Laborde, S., Guillén, F., \& Mosley, E. (2016). Positive personality-trait-like individual differences in athletes from individual- and team sports and in non-athletes. Psychology of Sport and Exercise, 26(September), 9-13. https://doi.org/10.1016/j.psychsport.2016.05.009

Merritt, C. J., \& Tharp, I. J. (2013). Personality, self-efficacy and risk-taking in parkour (free-running). Psychology of Sport and Exercise, 14(5), 608-611. https://doi.org/10.1016/j.psychsport.2013.03.001

Prakash, S., Singh, A., \& Yadav, S. K. (2016). Personality (Introvert, And Extrovert) and Professional Commitment Effect among B.Ed Teacher Educator Students. International Journal of Indian Psychology, 3(2). https://doi.org/10.25215/0302.040

Rhodes, R. E., \& Boudreau, P. (2017). Physical Activity and Personality Traits. Oxford Research Encyclopedia of Psychology, (March). https://doi.org/10.1093/acrefore/9780190236557.013.210

Roslan, N. S., Izhar, L. I., Faye, I., Amin, H. U., Saad, M. N. M., Sivapalan, S., .. Rahman, M. A. (2019). Neural correlates of eye contact in face-to-face verbal interaction: An EEG-based study of the extraversion personality trait. PLoS ONE, 14(7), 1-15. https://doi.org/10.1371/journal.pone.0219839

Salehi, A. (2010). The study of relationship among personality factors (introversion, extroversion) of students and their effects to selecting a good teacher. Procedia - Social and Behavioral Sciences, 2(2), 40164020. https://doi.org/10.1016/j.sbspro.2010.03.633

Setiawan, E., Budiarto, \& Afriyuandi, A. R. (2020). Korelasi Antara Physical Activity dan Physical Fitness Pada Atlet Bolabasket Level Pemula. Jurnal Pendidikan Olahraga dan Kesehatan, 9(2), 197-208. https://doi.org/10.31571/jpo.v9i2.2005

Setiawan, E., Patah, I. A., Bapista, C., Winarno, M. E., \& Sabino, B. (2020). Self-efficacy and mental toughness: Do psychological factors correlate with athlete performance?. Jurnal Keolahragaan, 8(2), 158-165. https://doi.org/10.21831/jk.v8i2.33551

Stylianos, K., Vasilios, K., Ethan, S., \& George, K. (2014). Development, validity and reliability of physical education instructor' s personality description scale. American Journal of Applied Psychology, 3(2), 39-46. https://doi.org/10.11648/j.ajap.20140302.13 
Sumantri, M. S., \& Pratiwi, N. (2015). The Effect of Learning Media and Types of Personality on Elementary Student's Mathematic Performance. American Journal of Educational Research, 3(3), 276-281. https://doi.org/10.12691/education-3-3-4

Zeichner, O. (2019). The Relationship Between Extrovert/ Introvert Attributes and Feedback on Students' Achievements. International Journal of Distance Education Technologies. 17(2), 1-2. https://doi.org/10.4018/IJDET.2019040101 